\title{
Incorporating Pet Fish Into Your Small Animal Practice ${ }^{1}$
}

\section{Ruth Francis-Floyd ${ }^{2}$}

Fish are the most popular pets in America, yet rarely benefit from veterinary care. More than 65 million fish are maintained in households throughout the United States, and fish owners frequently have other pets, such as dogs, cats, and birds. The value of individual fish can range from less than one dollar to many thousands of dollars for show quality Koi. Home aquarists, like other animal enthusiasts, often breed and show their pets and participate in special interest groups including local aquarium societies and national organizations such as the American Cichlid Association and the American Killifish Association. There are several factors that make it advantageous to consider adding pet fish medicine to your small animal practice at the present time. Over the past five to ten years, some veterinary schools have begun to incorporate aquatic animal medicine into their curricula. Many recent graduates have had some level of exposure to fish medicine as part of their veterinary education, and some individuals have had one or more intensive classes and/or clinical rotations in fish medicine. In addition, some veterinary colleges and national meetings now offer continuing education opportunities for graduate veterinarians in this area.
Concurrently, the Food and Drug Administration is determining which remedies sold for aquarium fish through the pet trade are appropriate for over-the-counter sales. It seems likely that some of these products will be removed from the market over the next few years, which may mean that aquarists will have to obtain certain medications, particularly antibiotics, through their local veterinarians. If veterinarians are going to serve this important component of the pet trade, the time to start preparing is now.

Unfortunately, there is a feeling in certain segments of the pet fish industry that veterinary interest in aquarium fish is purely profit motivated. In reality, it seems likely that it is related to the diversity of interests of veterinary students and recent graduates as well as to the maturation of aquaculture as an animal industry. Nonetheless, it is critical that veterinarians demonstrate their ability to make a real contribution to the aquarium trade, and this implies obtaining a basic level of expertise that will enable them to identify problems accurately, assess husbandry practices, and recommend therapy responsibly.

\footnotetext{
1. This document is VM147, one of a series of the Veterinary Medicine-Large Animal Clinical Sciences Department, Florida Cooperative Extension Service, Institute of Food and Agricultural Sciences, University of Florida. Original publication date August 12, 2003. Visit the EDIS Web Site at http://edis.ifas.ufl.edu.

2. Ruth Francis-Floyd, Professor, Department of Large Animal Clinical Sciences (College of Veterinary Medicine) and Department of Fisheries and Aquatic Sciences, Florida Cooperative Extension Service, Institute of Food and Agricultural Sciences, University of Florida, Gainesville, 32611.

The use of trade names in this publication is solely for the purpose of providing specific information. UF/IFAS does not guarantee or warranty the products named, and references to them in this publication do not signify our approval to the exclusion of other products of suitable composition.
}

The Institute of Food and Agricultural Sciences is an equal opportunity/affirmative action employer authorized to provide research, educational information and other services only to individuals and institutions that function without regard to race, color, sex, age, handicap, or national origin. For information on obtaining other extension publications, contact your county Cooperative Extension Service office. Florida Cooperative Extension Service/Institute of Food and Agricultural Sciences/University of Florida/Christine Taylor Waddill, Dean. 


\section{Types of Fish}

Although there are several thousand species and varieties of fish sold through the pet trade, Gratzek and Mathews (1993) have divided popular freshwater fish into seven main groups. The Cypinoids include tiger barbs, zebra danios, and goldfish. Many fish in this group are peaceful, hardy, and well suited to a community tank. Most live bearers are members of the family Poiciliidae, which includes the guppies, black mollies, swordtails, and platys. Fish in this group are peaceful, active, and ideal for beginners. The anal fin of the males is modified to form a gonodopodium, which is used for internal fertilization. The female is able to store the sperm for a period of time, and one breeding may result in more than one pregnancy. The gestation period is four to six weeks, and the live born young are able to eat a commercial dry diet immediately. Killifish are members of the family Cyprinodontidae. Although highly prized because of their bright coloration, they are ill suited to inexperienced aquarists. Their husbandry requirements are demanding, they are short-lived, and their temperament is often not suitable for a community tank. The Siluroid catfishes are popular aquarium pets. They are primarily bottom dwellers and effective scavengers.

Supplemental vitamin $\mathrm{C}$ is recommended for this group of fish and can be easily provided by adding sliced, parboiled zucchini to the diet. Characins, represented by tetras, are schooling fish and do well with a number of conspecifics in the same tank with a large swimming area. The Cichlids are an extremely popular group of fish consisting of species from the Amazon River as well as the Rift Lakes in Africa. Some species, such as the angel fish, are suitable for community tanks, while others, such as the oscar, are predacious and can only be kept with fish of similar size. Cichlids are intelligent and colorful, and many species provide substantial parental care to their offspring, making them particularly interesting to the hobbyist breeder. The Anabantoids and other labyrinth fishes are specially equipped to utilize atmospheric oxygen by breathing air just above the surface of the water. Two popular fish in this group are the gouramis and the Siamese fighting fish. The practitioner is encouraged to read several of the excellent books available on natural history and husbandry of specific groups of aquarium fish. There are many exceptions to the general comments above.

Tropical marine fish and invertebrates are popular and valuable aquarium pets. With the exception of clown fish, almost all marine fish are wild caught. Management of a marine aquarium is challenging as the fish require a stable environment and nutritional needs may be unknown or difficult to meet. Disease processes of marine fish are often poorly understood, and therapeutic options are limited.

Table 1. Suggested water quality equipment for a veterinary practice providing service to pet fish clientele.

\begin{tabular}{|c|c|c|}
\hline TEST KIT & RANGE & cost \\
\hline FF-1A Aquaculture Kit & & $\$ 176.00$ \\
\hline Alkalinity & $0.4-8 \mathrm{gpg}^{\mathrm{b}}$ & \\
\hline Ammonia & $\begin{array}{l}0-3 \mathrm{mg} / \mathrm{L} \text { as } \\
\mathrm{NH}-\mathrm{N}\end{array}$ & \\
\hline Carbon dioxide & $\begin{array}{l}5-100 \\
\mathrm{mg} / \mathrm{L}\end{array}$ & \\
\hline Chloride & $\begin{array}{l}5-400 \\
\mathrm{mg} / \mathrm{L}\end{array}$ & \\
\hline Dissolved oxygen & $\begin{array}{l}0.2-20 \\
\mathrm{mg} / \mathrm{L}\end{array}$ & \\
\hline Hardness & $\begin{array}{l}1-30 \mathrm{gpg}^{\mathrm{b}} \\
\text { as } \mathrm{CaCO}\end{array}$ & \\
\hline Nitrite & $\begin{array}{l}0-0.5 \mathrm{mg} / \mathrm{L} \\
\text { as NO -N }\end{array}$ & \\
\hline $\mathrm{pH}$ & $\begin{array}{l}4-10 \mathrm{pH} \\
\text { units }\end{array}$ & \\
\hline Temperature & $\begin{array}{l}-30^{\circ} \text { to } \\
120^{\circ} \mathrm{F}\end{array}$ & \\
\hline Saltwater Master Test Kit & & $\$ 35.75$ \\
\hline Ammonia & $0-3 \mathrm{mg} / \mathrm{L}$ & \\
\hline Nitrate & $0-50 \mathrm{mg} / \mathrm{L}$ & \\
\hline Nitrite & $0-0.75 \mathrm{mg} / \mathrm{L}$ & \\
\hline $\mathrm{pH}$ & $6.5-8.5 \mathrm{pH}$ & \\
\hline Chlorine & & $\$ 32.50$ \\
\hline Free and total chlorine & $0-3.5 \mathrm{mg} / \mathrm{L}$ & \\
\hline Copper & & $\$ 27.50$ \\
\hline Free copper (low range) & $0-2.5 \mathrm{mg} / \mathrm{L}$ & \\
\hline \multicolumn{3}{|c|}{$\begin{array}{l}{ }^{a} \text { Prices listed are from Hach Company, } 1993-4 \text { catalog, } \\
\text { Loveland, CO. Similar products are available from other } \\
\text { sources. } \\
{ }^{\mathrm{b}} 1 \mathrm{gpg}=17 \mathrm{mg} / \mathrm{L} \text { or } 17 \mathrm{ppm}\end{array}$} \\
\hline
\end{tabular}




\section{Special Equipment Needed}

Most veterinary practices will have most of the equipment needed for handling fish patients. Basic equipment includes a light microscope, glass slides, cover slips, scalpel, forceps and small, curved scissors. Special equipment specifically for fish includes water-quality testing equipment (Table 1), a few small aquaria (5 or 10 gallons each) for hospitalization or treatment administration, an air pump, plastic tubing, sponge filters, nets, buckets, a source of dechlorinated water or a chemical dechlorinator, and sea salts. An initial investment of $\$ 200$ to $\$ 400$ should be adequate.

\section{Clinical Evaluation of Pet Fish}

\section{History}

Initial assessment of the fish patient will usually be made while the history is taken (Table 2).

Table 2. Key questions for taking a history for a pet fish problem.

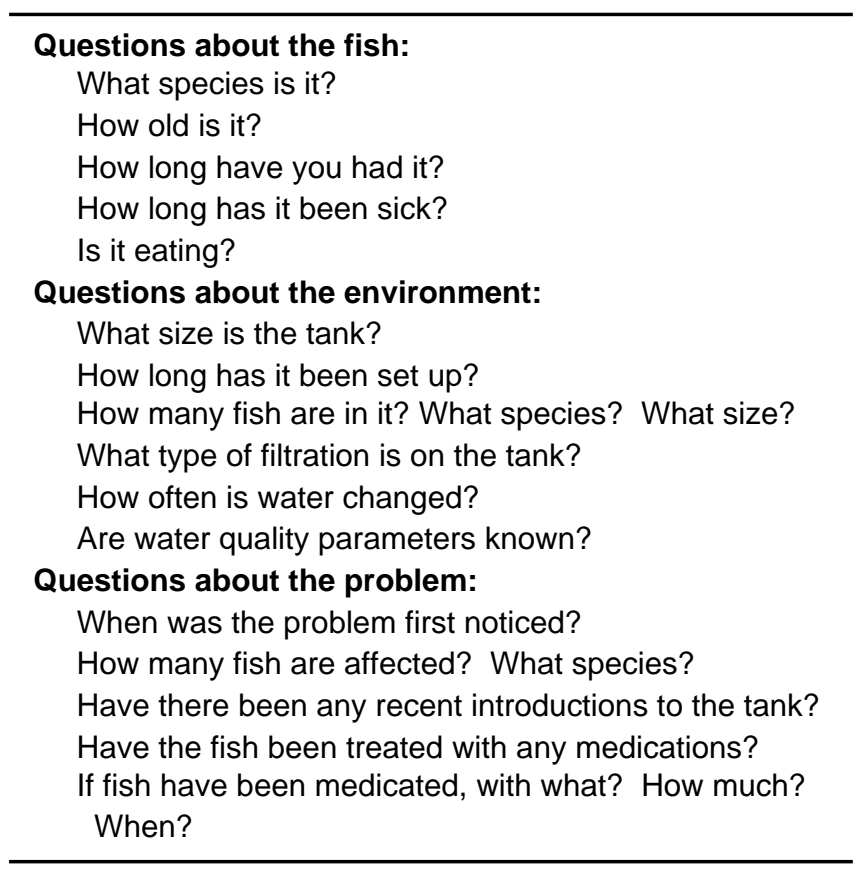

This may be done over the phone or in the office. Key information should include the species of fish involved, the number of fish involved, and the period of time the problem has been in progress. The size of the aquarium or pond should be determined, along with stocking density, feeding rate, how long the aquarium or pond has been set up, how long affected fish have been in the system, and when the most recent introduction of new fish occurred. Finally, it is important to ask whether or not fish have been medicated recently and, if so, with what. Questions regarding product use are appropriate and provide a means of determining whether the dosage administered was appropriate.

\section{Sample Submission}

Once it has been determined that the fish (one or more patients) is to be brought into the clinic, the owner must be instructed on how to submit a sample. A water sample is extremely important and can be collected in any clean glass jar. Although only about 100 milliliters are needed for routine analysis, it is a good idea to recommend that the client fill a clean quart jar to assure that plenty of water is available in case some gets spilled or additional tests are required. Water samples should be free of air pockets and submitted, with a separate fish sample, on ice. Water that the fish is transported in is not representative of water in the tank.

A live fish can be transported in a bucket or cooler partially filled with water. Aeration with a battery-powered pump is recommended if the fish is to be in transit longer than 30 to 60 minutes. If the fish is to be shipped from any distance, it can be live-packed into an oxygen-filled bag (with 30\% water) and then placed in an insulated (e.g., styrofoam) container and shipped by bus or by air to the clinic. Many people use overnight mail to move fish rapidly around the country. A dead fish should be wrapped in a wet paper towel and transported on ice. A fish that has been dead for more than 15 to 30 minutes prior to being placed on ice is not suitable for examination.

\section{Assessment of Husbandry}

\section{Water Quality}

The most important aspect of fish health management is maintenance of proper water quality. There is a great deal of variation in the tolerance of different groups of fish; however, some general guidelines are provided in Table 3. The most common water quality problem in home aquaria usually involves accumulation of nitrogenous waste, 
particularly ammonia. This is often caused by overfeeding or inadequate biofiltration. Biofilter failure is commonly caused by inadequate flow, which may be caused by a dirty filter. Biological degradation of ammonia (Figure 1) is an aerobic bacterial process, and a filter that becomes clogged by accumulation of organic debris often develops anaerobic areas, resulting in poor performance. Ammonia toxicity can be acute or chronic, but in either case it becomes more serious as $\mathrm{pH}$ and temperature rise. Diagnosis of ammonia toxicity can only be done by testing the water. Immediate treatment involves changing the water; however, it is important to determine whether equipment failure or improper husbandry practices contributed to the problem. Low oxygen can be an important problem in ornamental ponds, particularly those with heavy algal blooms (visibility 18 inches or less) and marginal aeration. Heavy algal blooms are often associated with overfeeding and/or overstocking. A good rule of thumb is one inch of fish per gallon of water. Feeding should be limited to once or twice a day, and fish should only be fed what they will eat in 10 minutes or so. Oxygen problems in home aquaria are rare and usually are caused by equipment failure (e.g., loss of electrical power to the home).

Other water quality parameters that can be important are $\mathrm{pH}$, temperature, total alkalinity, and salinity in seawater systems. The practitioner is encouraged to pursue supplemental reading on water quality and general aquariology to improve his or her expertise in the area. A reading list is provided at the end of this article. Failure to have some understanding of the aquatic environment is one of the quickest ways for a practitioner to lose his or her credibility with prospective fish-owner clients.

Water quality problems can cause catastrophic losses. If all fish in a system die suddenly within a 24 hour period, a water quality problem is the most likely explanation.

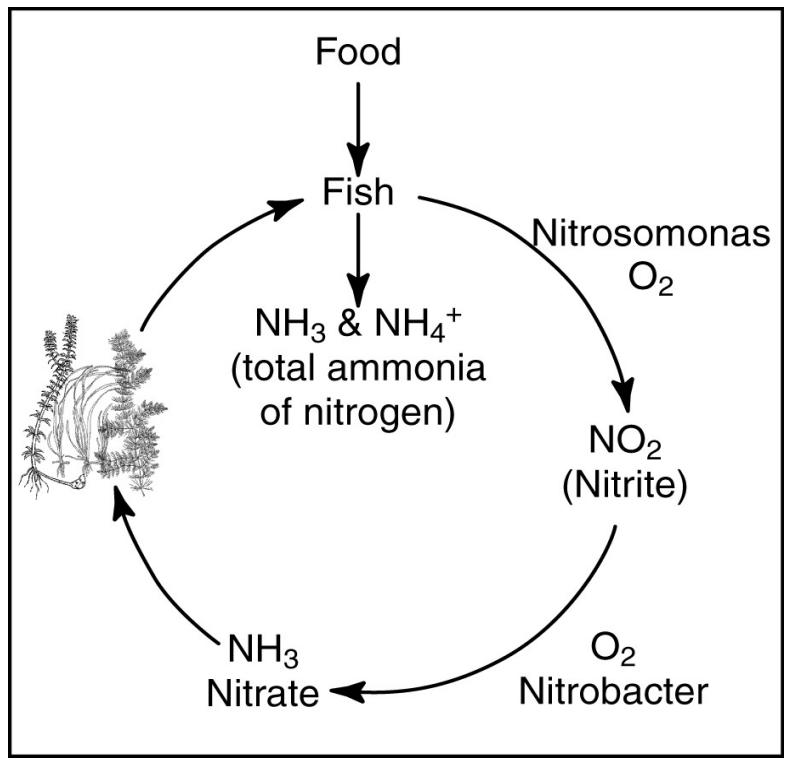

Figure 1. Biological degradation of ammonia

Table 3. General guidelines for water quality

\begin{tabular}{|c|c|c|}
\hline \multirow[t]{2}{*}{ Parameter } & \multicolumn{2}{|c|}{ Desirable Range } \\
\hline & Freshwater & Marine \\
\hline Dissolved Oxygen & $\geq 5 \mathrm{ppm}$ & $\geq 5 \mathrm{ppm}$ \\
\hline $\mathrm{pH}$ & $6.0-9.0$ & 8.2-8.3 \\
\hline $\begin{array}{l}\text { Total ammonia } \\
\text { nitrogen }\end{array}$ & 0 ppm & 0 ppm \\
\hline Nitrite & 0 ppm & 0 ppm \\
\hline Chloride & $\geq 20 \mathrm{ppm}$ & $N A^{b}$ \\
\hline Salinity & $N A^{c}$ & $33 \mathrm{ppt}$ \\
\hline Total Alkalinity & $50-250$ ppm & $\geq 250 p p m$ \\
\hline Total Hardness & $50-250$ ppm & $\geq 250 \mathrm{ppm}$ \\
\hline \multicolumn{3}{|c|}{$\begin{array}{l}\text { NA: Not applicable } \\
{ }^{\mathrm{a}} \text { Temperature is not listed because } \\
\text { temperature requirements of different species } \\
\text { are so variable. In general, tropical species, } \\
\text { both freshwater and marine, prefer } \\
\text { temperatures in the range of } 75^{\circ} \mathrm{F} \text { to } 80^{\circ} \mathrm{F} \text {. } \\
{ }^{\mathrm{b}} \text { Chloride concentrations are not measured in } \\
\text { saltwater systems; instead, salinity levels are } \\
\text { monitored. } \\
{ }^{\mathrm{C}} \text { Salinity is not generally measured in } \\
\text { freshwater systems, although concentrations of } \\
0.02 \text { to } 0.5 \%(0.2 \text { to } 5 \mathrm{ppt}) \text { are recommended } \\
\text { for recirculating systems. }\end{array}$} \\
\hline
\end{tabular}

\section{Nutrition}

Feeding of pet fish is often limited to products sold through the pet trade. While many of these 
products are excellent, it is important to educate the client on proper food storage and to purchase products that are fresh. Few fish foods are labeled with an expiration date, but food products should be discarded after two to three months. In addition, it is wise to purchase foods from a store that moves a large amount of product to increase the likelihood of freshness. Supplemental foods, particularly fresh vegetables (zucchini flakes, romaine lettuce, spinach, peas, and bok choy), are strongly recommended for many fish. Carnivorous fish should be fed some live food (e.g. brine shrimp, feeder fish, etc.), although there is always a risk of introducing disease with live foods. An ideal arrangement for the serious hobbyist would be maintenance of a culture of live bearing fish (e.g., common mosquito fish, Gambusia sp.) to minimize the risk of introducing disease to a valuable collection.

\section{Sanitation}

Sanitation is just as important for maintaining healthy fish as for any other population of animals. Accumulations of organic matter favor multiplication of opportunistic pathogens in the environment and contribute to water quality problems. If tanks are established and not overfed, they can be cleaned once a week by siphoning debris (uneaten food, fecal material, etc.) from the bottom of the tank and changing about $20 \%$ of the water. During the first 6 weeks that a tank is set up, water quality problems should be anticipated and tested for and more frequent water changes should be carried out if ammonia or nitrite levels rise. For clients with more than one tank, particularly breeders or retailers, either each tank should have its own net and set of equipment or a net dip (quaternary ammonium compounds work well) should be used. If nets or equipment are chemically disinfected, they must be rinsed well before being placed into contact with fish. Tanks and other equipment can be disinfected with chlorine $(10 \mathrm{mg} / \mathrm{l})$ for one hour; however, chlorine residue must be completely removed before they are placed into contact with fish. Never use chlorine bleach in a closed room containing live fish or to disinfect porous surfaces. Chlorine residue can be removed by using $7.4 \mathrm{ppm}$ sodium thiosulfate to neutralize each 1 ppm chlorine.

\section{Quarantine}

Quarantine is not always popular with aquarists, but introduction of a newly acquired fish directly into an established aquarium is foolish. Some pet stores are equipped to quarantine fish for the owner following purchase. This is a service that could also be offered by veterinary practitioners. The quarantine period should be at least three weeks. During this time the fish should be kept in a small hospital tank where it is accessible for observation, physical examination, gill and skin biopsies, fecal examination, and medication if necessary. A 10-gallon tank with a sponge filter is ideal for quarantine of small fish. The filter may be discarded at the end of the quarantine period or can be thoroughly washed (a household washing machine works well), dried, and recycled with ammonium chloride or fish food.

\section{Examination of Fish}

\section{$\underline{\text { Restraint }}$}

Many fish can be examined with nothing more than manual restraint. Fish should be placed on a wet surface for examination. Many fish seem to stop struggling if the eyes are covered. If the fish is too large to handle safely or will not settle down, chemical restraint can be provided using methane tricainesulfonate (MS-222). Finquel (Argent Chemical, Redmond, WA) is a brand of MS-222 that has been approved by the food and Drug Administration for use in food fish. Induction can be achieved with a concentration of 50 to $100 \mathrm{mg} / \mathrm{l}$, which seems to be safe for most species. The compound is acidic and should be buffered to a $\mathrm{pH}$ of 7.0 to 7.5 , which can be done by adding sodium bicarbonate $(\mathrm{NaHCO} 3)$ to saturation. Any anesthetic solution should be well aerated. Following induction, anesthesia can usually be maintained with a concentration of 50 to $75 \mathrm{mg} / \mathrm{l} \mathrm{MS}-222$. While the fish is anesthetized, it should be monitored for respiratory movement. If the operculum stops pumping at any time, the fish should be placed into clean water immediately.

\section{$\underline{\text { External Examination }}$}

External, physical examinations of fish are done in the same way as examinations of other animals. 
Beginning with the head, a fish should be examined for lesions, body condition, and finnage. Eyes should be clear, not cloudy or exophthalmic; gills should be bright red, not swollen, pale, or puffy; and the mouth should be clean with no lesions, fuzzy areas, or organisms visible. The best way to evaluate body condition on most fish is to assess the amount of muscle tissue behind the head, anterior to the dorsal fin. The best indicators of weight loss are a thinness behind the head and protrusion of the backbone. Skin and scales should be bright and intact. Loss of scales, ulcerations, dullness, or excessive mucus accumulation may indicate external parasitism or bacterial infection. Fins should be intact, not tattered, fuzzy, or bloody.

\section{$\underline{\text { Biopsies of Gill, Skin, and Fin }}$}

Examination of fresh material collected from gills, skin, and fins of fish is an important part of the examination process. The tip of a few gill filaments can be snipped with a small pair of scissors. Iridectomy scissors are ideal, if available; however, any small pair of scissors with curved tips are adequate. Embroidery scissors are particularly well suited for gill biopsy. A sample of skin mucus and scales can be collected by gently scraping a glass coverslip over the surface of the fish. If the fish is not going to be sacrificed, be sure to keep the area sampled to a minimum. Areas of particular interest should be lesions, bumps, or ulcers. As in other species, the edge of an abnormal area is most suitable for examination. Fin biopsies can be taken by gently snipping a section of fin and preparing a wet mount. Any abnormal or frayed area is best. Wet mounts of gill filaments, skin mucus, and fin edge can be examined, without staining, at 100x and 400x with a light microscope. Parasites can be identified by their movement or shape. A number of references are available to assist you in learning to identify different organisms (see Recommended Reading). In addition to identification of organisms, it is important to assess the number of organisms present and the general condition of the tissue being examined, particularly the condition of gill filaments (Figure 2).

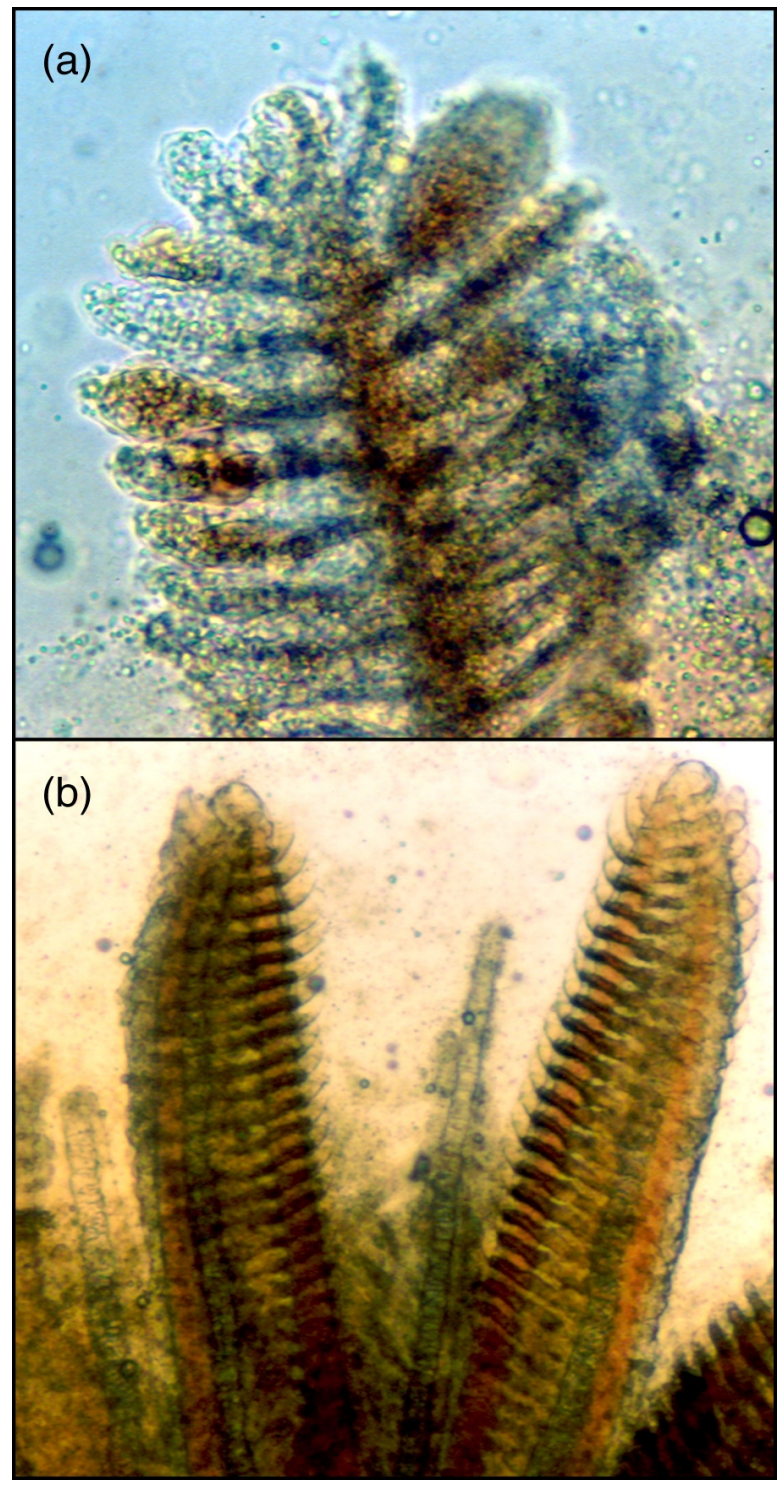

Figure 2. Assess gill filament condition

\section{$\underline{\text { Fecal Examination }}$}

Intestinal parasitism can be of concern in a number of popular species of aquarium fish, including many freshwater cichlids and tropical marine reef fish. A fecal sample can sometimes be collected by gently squeezing the abdomen of the fish. If the fish has been anorectic, however, this may not work well. If the fish is anesthetized to ease handling, collection of a fecal sample can often be accomplished during induction, as defecation is common at this time. If the fish is to be necropsied, intestinal contents can be examined with a light microscope after the abdominal cavity has been opened. A negative fecal does not mean that the fish 
is free of parasites, as some parasites inhabit the anterior portions of the intestinal tract. However, a positive result indicates that parasites are present, although it may be difficult to assess the severity of the infestation.

\section{Necropsy}

Many breeders will be willing to sacrifice several fish from a population for complete necropsy in order to obtain a more accurate diagnosis than could be obtained from examination of a live fish. It is important to communicate clearly with the client before the decision to euthanize a fish is made. Euthanasia can be readily accomplished by using an overdose of MS-222 or by simply severing the spinal cord. The principal advantages of complete necropsy are that it provides a means of obtaining tissue samples for bacterial or viral culture as well as for histologic examination. Of these, bacterial cultures are the most important for routine problems. Bacterial cultures should be taken from posterior kidney and other organs as indicated. Brain cultures are particularly important if the fish shows signs of neurologic disease (i.e., spinning, convulsing, etc.). Bacterial cultures should be sent to a laboratory familiar with fish samples. Most bacteria of fish grow best at $25^{\circ} \mathrm{C}$ rather than $37^{\circ} \mathrm{C}$ and may not key out properly with identification kits used for mammalian samples.

\section{Common Diseases}

\section{Bacterial Diseases}

Bacterial diseases are common in fish; however, in most cases it is prudent to determine why the fish was susceptible to bacterial invasion. Poor water quality, dirty conditions, and excessive parasitism often predispose fish to bacterial infections. With the exception of Streptococcus, which is rare, most bacterial infections of fish are caused by gram negative organisms. Aeromonas hydrophila is the most common bacterial pathogen infecting warmwater fish. The disease often presents with low to moderate levels of mortality, hemorrhage of fins and skin, and fluid accumulation. Pseudomonas florescens can mimic A. hydrophila infections in warmwater fish. A closely related disease that is common in goldfish and koi carp is Aeromonas salmonicida, which can cause a chronic, fibrinous peritonitis in some fish. Members of the genus Vibrio are the most common bacterial pathogens of marine fish, and clinical presentation is very similar to $A$. hydrophila infection of freshwater fishes.

Occasionally, Streptococcus or Edwardsiella ictaluri will be isolated from the brains of fish showing signs of neurologic disease, often manifested by spinning. Edwardsiella tarda and $P$. putrifaciens are occasionally isolated from malodorous ulcers on fish and can cause systemic disease. Flexibacter columnaris is a bacterium that infects epithelial surfaces and is a common cause of fin rot. External infections of $F$. columnaris can be presumptively identified with a light microscope. Long flexing rods typical of the organism can be seen at 400x. Ordals is a special medium used for isolation of columnaris bacteria. Bacterial culture and antibiotic sensitivity testing is extremely important for pet fish. Trypticase Soy Agar with 5\% bovine or ovine blood is ideal for primary isolation of most bacteria. Mueller Hinton medium is effective for most sensitivity testing.

\section{Parasitic Diseases}

Experience at the University of Florida suggests that the most common infectious disease problems of pet fish are parasitic. Goldfish and koi, for example, are commonly presented with heavy infestations of monogenetic trematodes on the gills and skin. Monogenes can occur on any species; however, goldfish, koi, and discus (an Amazon cichlid) seem highly susceptible. Monogenes are easily recognized as flatworms visible under low power (40x) with a light microscope. They move in an inchworm fashion and attach to host epithelium with hooks.

Ichthypothirius multifiliis, commonly called ich, is a ciliated protozoan that is an obligate parasite of fish. Ich is very large (1000um) and easily seen using low power (40x). It appears as a large, dark organism covered with cilia. It has a horseshoe-shaped macronucleus and moves in a tumbling or ameboid fashion. A similar organism, Cryptocaryon irritans, causes ich in saltwater fish. Icthyobodo (previously known as Costia) is a small flagellate that attaches to the gills or skin of fish. This parasite is commonly missed by experienced aquarists who scope their own 
fish. It is difficult to recognize at magnification less than 400x, but its characteristic corkscrew-like swimming pattern will suggest its presence to the careful observer. Once it attaches to gill or skin epithelium, it is difficult to see without oil immersion. The best place to look for this parasite is on the edge of the gill filament or skin mucus.

A final parasite worthy of individual mention is Hexamita (soon to be renamed Spironucleus), an intestinal flagellate common in the gut of cichlids but also found in other species. A typical case history includes chronic weight loss, decreased fecundity, and poor survival of fry. The organism is easily identified in fecal smears or wet mounts of intestinal tissue examined under 100x to 400x magnification. The organism, if problematic, will be present in large numbers, and the intestinal contents will be alive with small, rapidly moving flagellates. Clinical disease attributed to Hexamita seems most pronounced in fish maintained under unsanitary conditions or subjected to recent shipment and handling.

\section{Fungal Disease}

Although several systemic fungal diseases of fish have been reported, the most common fungal infections are limited to epithelial surfaces of gill, skin, or fin. In general, most of these are arbitrarily assigned to the genus Saprolegnia and can be presumptively identified by the presence of broad, aseptate hyphae from suspect lesions. Should fungal cultures be desired, Sabaroud-Dextrose medium is a good choice for initial isolation. Most external fungal infections are secondary to husbandry problems, particularly overcrowding and poor sanitation.

\section{Viral Diseases}

Although there are some viral diseases of tropical fish, most are poorly understood, and diagnosis is based on ruling out other problems. Lymphocystis is caused by an iridovirus and can infect many species of fish. It results in blister-like skin lesions caused by hypertrophy of epithelial cells and can be presumptively identified by the appearance of giant cells in skin scrapings of suspect lesions.
Recently, an iridovirus has been associated with systemic disease in gouramis. Affected populations can suffer significant mortality $(>50 \%)$.

A paramysovirus was associated with systemic disease and heavy mortality ( $>50 \%)$ of angelfish in 1990. Infected fish huddled in corners, clamped their fins together, and often developed severe tail rot in the absence of obvious parasites or bacteria.

A retrovirus has been associated with the presence of lip fibromas in angelfish (Figure 3); but affected fish were not systemically ill, and surgical removal of the mass was effective.

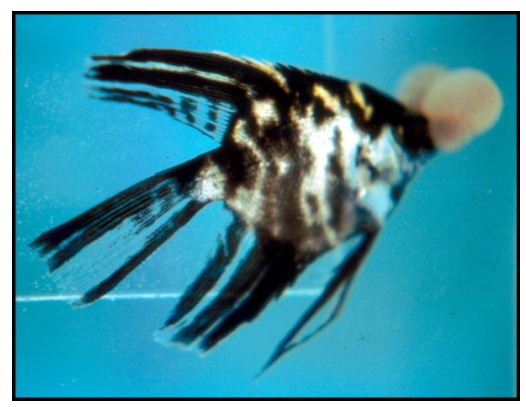

Figure 3. Lip fibromas in angelfish

\section{Treatment of Common Diseases}

\section{Treatment of External Parasitic, Bacterial, and Fungal Infections}

Most external parasite infections of fish can be controlled with one of the following compounds: salt, formalin, potassium permanganate $(\mathrm{KMnO} 4)$, or copper sulfate (CuSO4). All are similarly effective, although potassium permanganate may be a little more efficacious against Saprolegnia and columnaris bacteria (external infections only).

Although not specifically approved for aquaculture use, salt has been designated as a low regulatory priority compound by the FDA, and its use is widespread in most aquaculture industries. It can be added to freshwater recirculating systems or small ornamental ponds as a permanent treatment at concentrations of 0.02 to $0.1 \%$, depending of the species of fish. At this concentration, most chronic problems caused by protozoans will be eliminated. When receiving a new group of fish, a 3\% salt dip will effectively eliminate many external parasites from freshwater fish, whereas a freshwater dip will similarly benefit marine fish. 
Formalin is FDA approved for control of external parasites on channel catfish, salmonids, and paneid shrimp. It is effective against monogenes and many protozoans.

Formalin can be added to aquaria at a concentration of $25 \mathrm{mg} / \mathrm{L}$ for a long-term bath, which is approximately $1 \mathrm{ml}$ per 10 gallons of water. Short-term baths of $250 \mathrm{mg} / \mathrm{L}$ for 30 to 60 minutes can be used to treat fish in the clinic. However, treatment of a sick animal can result in its death, so be cautious and never leave a fish unattended during treatment. Formalin is algicidal, and each $5 \mathrm{mg} / \mathrm{L}$ chemically removes $1 \mathrm{mg} / \mathrm{L}$ dissolved oxygen from water, so aeration is mandatory during treatment. For this reason, formalin is not recommended for use in ornamental ponds with marginal aeration and/or heavy algal blooms.

Potassium permanganate is not FDA approved, but has been used for many years by aquaculturists as an oxidizing agent. It effectively eliminates many parasites as well as bacteria and fungi from the external surface of fish. It is caustic to epithelial surfaces, however, and should never be used more than once a week. Potassium permanganate should be delivered at a concentration of $2 \mathrm{mg} / \mathrm{L}$ as a prolonged bath. Delivery of the chemical to aquarium systems is best accomplished by using a stock solution. For $\mathrm{KMnO}$, a stock solution that will deliver the desired concentration $(2 \mathrm{mg} / \mathrm{L})$ can be prepared by dissolving $285 \mathrm{~g}$ of the chemical into 1 gallon of distilled water and dispensing a dose of 2 drops per gallon. This concentration should change the water to a light pink color. If the water color changes from pink to brown, or clears, in less than four to six hours, the treatment may not have been effective. Potassium permanganate is quickly deactivated in water that has a heavy organic load. To compensate for this, the treatment can be repeated, in $2 \mathrm{mg} / \mathrm{L}$ increments, until a concentration of $6 \mathrm{mg} / \mathrm{L}$ has been achieved. If it is still not possible to maintain a pink color for four hours (from the time of the first application of $\mathrm{KMnO} 4$ ), the system should be cleaned and the problem reevaluated. A short-term bath of $\mathrm{KMnO} 4$ can be delivered by using $10 \mathrm{mg} / \mathrm{L}$ for 30 minutes.

Copper sulfate is extremely effective against protozoans and is inexpensive. Although not FDA approved for this purpose, it is EPA approved as an algicide and has been used extensively in commercial aquaculture for many years. Copper sulfate is very toxic to fish and so must be used carefully in a system containing live fish. For freshwater systems, a safe way of achieving this is to titrate the concentration of $\mathrm{CuSO} 4$ based on the total alkalinity of the water. Total alkalinity (TA) can be quickly measured with a test included in the Hach kit (\#FF-1A). If TA is less than $50 \mathrm{mg} / \mathrm{L}, \mathrm{CuSO} 4$ is contraindicated. If TA is between 50 and $250 \mathrm{mg} / \mathrm{L}$, the concentration of $\mathrm{CuSO} 4$ should equal TA/100. For example, if TA is $100 \mathrm{mg} / \mathrm{L}$, then the desired concentration of $\mathrm{CuSO} 4$ is $100 / 100=1 \mathrm{mg} / \mathrm{L}$. If TA is greater than $250 \mathrm{mg} / \mathrm{L}$, the concentration of $\mathrm{CuSO} 4$ delivered should not exceed $2.5 \mathrm{mg} / \mathrm{L}$. A stock solution can be made by dissolving $285 \mathrm{~g} \mathrm{CuSO} 4$ into one gallon of distilled water. The stock solution mentioned above will deliver $1 \mathrm{mg} / \mathrm{L} \mathrm{CuSO} 4$ for every drop per gallon dispensed. Copper sulfate must be used with caution in ponds because it is a powerful algicide and can cause a catastrophic oxygen depletion. Aeration must be provided when treating fish with any chemical.

Determining how much chemical to add to a system to achieve a specific concentration is fairly straightforward as long as the volume of the system is known. Most aquarists determine volume in gallons, and 0.0038 grams of anything, dissolved in one gallon of water, is equal to $1 \mathrm{mg} / \mathrm{L}$. Table 4 gives several examples of how this information can be used to calculate the amount of chemical to deliver in an aquarium system.

\section{Treatment of Systemic Bacterial Infections}

Use of antibiotics in fish should be based on results of sensitivity testing whenever possible. Since most bacterial infections of fish are gram negative, oxytetracycline is a good broad-spectrum antibiotic that can be delivered in feed, by injection, or in a bath. Baths should only be used when fish are not feeding and injection is not practical. Bath treatments should deliver no less than $750 \mathrm{mg}$ oxytetracycline per 10 gallons of water and must be repeated daily for 10 days. Oral medications should provide $55 \mathrm{mg}$ oxytetracycline per $\mathrm{kg}$ body weight for 10 days. 
Because pet fish patients are so small, it is often necessary to estimate the amount of antibiotic to add to the feed. One gram active drug per pound of feed is a good rule of thumb for many antibiotics. Commercial flake diets are available that contain Terramycin, a product containing oxytetracycline that is FDA approved for use in catfish and salmonids.

Romet is a potentiated sulfonamide containing ormetoprim and sulfadimethoxine. It is FDA approved for use in catfish and salmonids and is available in a flake food for tropical fish. The desired dose is $50 \mathrm{mg}$ active drug per $\mathrm{kg}$ body weight for 5 days. Romet is not water soluble, so it is not suitable for bath treatments and is not available in an injectable form.

Erythromycin delivered in feed at a dose of 100 $\mathrm{mg} / \mathrm{kg}$ for14 days is the treatment of choice for Streptococcus infections. At the present time, erythromycin is not labeled for aquaculture use.

\section{Treatment of Internal Parasitism}

Metronidazole is the treatment of choice for Hexamita infections. It can be delivered orally at a dose of $50 \mathrm{mg} / \mathrm{kg}$ (approximately $4.5 \mathrm{~g}$ per pound of food) for five consecutive days. There is a commercially available flake food that contains metronidazole. If fish are anorectic, metronidazole can be provided as a bath delivered at a concentration of $5 \mathrm{mg} / \mathrm{L}$ (approximately $250 \mathrm{mg}$ per 10 gallons) daily for five consecutive days.

Although tapeworms have not been discussed, the practitioner should be aware that praziquantel is extremely effective in fish and can be delivered as a bath $(10 \mathrm{mg} / \mathrm{L}$ for three hours) or in a medicated food (100 mg/25g food, daily for seven days).

Praziquantel is also effective against monogenetic trematodes, and there are anecdotal reports that it has some efficacy against degenetic trematodes as well.

Fenbendazole can be used to control enteric nematodes, although complete information on safety and efficacy is lacking. Angel fish in our laboratory that were treated with $11 \mathrm{mg} / \mathrm{kg}$ orally for two days had some benefit from fenbendazole, however, efficacy of a three- to five-day treatment regime should be evaluated.

\section{Summary}

Pet fish medicine provides a unique opportunity for small animal practitioners to build their practices by serving a group of clients who have historically been neglected. An increase in demand for veterinary service is anticipated as the aquarium hobby matures and realizes the benefits of accurate diagnosis, responsible therapy, and preventive medicine programs. Veterinarians willing to provide this service must take it upon themselves to attain a level of expertise that will allow them to make substantial contributions to the well-being of their clients' animals and businesses.

\section{Recommended Reading}

Brown, L. A. (Ed). 1993. Aquaculture for Veterinarians: Fish Husbandry and Medicine. Pergamon Press, Oxford. 447 pp.

Gratzek, J. B., and Mathews, J. R. (Eds) 1993. Aquariology: The Science of Fish Health Management. Tetra Press, Morris Plains, NJ. 330 pp.

Post, G. 1987. Textbook of Fish Health, Second Edition. TFH Publications, Neptune City, NJ. 288 pp.

Roberts, R. J. (Ed). 1989. Fish Pathology, Second Edition. Bailliere Tindall, London. 467 pp.

Stoskopf, M. K. (Ed). 1993. Fish Medicine. W. B. Saunders Company, Philadelphia. 882 pp.

Stoskopf, M. K. (Ed). 1988. Tropical Fish Medicine. Veterinary Clinics of North America: Small Animal Practice 18(2);474. 
Table 4. Examples of calculations used to determine amount of chemical required to deliver a specific concentration of compound to an aquarium system.

\begin{tabular}{|c|c|c|}
\hline Chemical & Desired Concentration & Formula \\
\hline Formalin & 25 mg/L. (2 drops/gal.) & $\begin{array}{l}125 \mathrm{gal} X 2 \mathrm{drops} / \mathrm{gal}=250 \mathrm{drops} \\
(12.5 \mathrm{ml})\end{array}$ \\
\hline $\begin{array}{l}\text { Potassium } \\
\text { Permanganate }\end{array}$ & $2 \mathrm{mg} / \mathrm{L}$ & $\begin{array}{l}125 \mathrm{gal} X 2 \mathrm{mg} / \mathrm{L} \times 0.0038=0.95 \\
\text { gram }\end{array}$ \\
\hline Copper Sulfate & $\begin{array}{l}\text { Total alkalinity } / 100 \\
\text { if tot. alk. = } 50-250 \mathrm{mg} / \mathrm{L} \\
\text { (Assume tot. alk. is } 220 \\
\mathrm{mg} / \mathrm{L} \text { ) }\end{array}$ & $\begin{array}{l}125 \mathrm{gal} X 220 / 100 \times 0.0038=1.0 \\
\text { gram }\end{array}$ \\
\hline $\begin{array}{l}\text { Masoten } 80 \% \text { wettable } \\
\text { powder }\end{array}$ & $\begin{array}{l}0.25 \mathrm{mg} / \mathrm{L} \text { (For a product } \\
\text { that is only } 80 \% \text { active, use } \\
100 / \% \mathrm{Al}=100 / 80=1.25 \text { ) }\end{array}$ & $\begin{array}{l}125 \mathrm{gal} X 0.25 \mathrm{mg} \mathrm{LX} 0.0038 X \\
1.25=0.15 \mathrm{gram}\end{array}$ \\
\hline Salt & $\begin{array}{l}0.2 \%=2 \mathrm{ppt}=2000 \mathrm{ppm}= \\
2000 \mathrm{mg} / \mathrm{L}\end{array}$ & $\begin{array}{l}125 \mathrm{gal} \times 2000 \mathrm{mg} / \mathrm{L} \times 0.0038= \\
950 \text { grams }=2.1 \mathrm{lbs}\end{array}$ \\
\hline
\end{tabular}

